\title{
The Development of Renewable Energy in Buildings in UAE
}

\author{
Riadh AL-Dabbagh ${ }^{*}$ \\ Ajman, 346 Ajman UAE \\ Email: riadhdabbagh46@gmail.com
}

\begin{abstract}
Low energy buildings Projects focuses on active houses, which are not only buildings, but active components in the overall integrated energy systems. The target is to demonstrate affordable solutions for social housing and revitalization of town areas. The solutions will reduce $\mathrm{CO}_{2}$ at no or negative cost seen in a total perspective. Targeted $\mathrm{CO}_{2}$ reduction cost, the reason is because UAE having one of the largest carbon footprints on the planet, and it can be minus taking the benefits of lower energy bills into account, to even better figures when national grants are included. It is possible to simultaneously save $\mathrm{CO}_{2}$ and money! Key barrier is the initial investment, few technologies are being developed in buildings such as photovoltaic building elements, dual function insulation, double glazed windows, and ICT solutions. demonstration projects were independent from each other, being designed to fulfil local energy needs and using local resources, there were many similarities between them. It's not easy being green, at least in the UAE, where scorching summers make air conditioning as essential as the millions of gallons of desalinated seawater which keep most of the country's plant life from turning brown and crispy. But while the region has a well-founded reputation for having one of the largest carbon footprints, a number of projects demonstrate how environmental principles are at the foundation of many of the country's most exciting new developments.
\end{abstract}

\section{Introduction}

In the past, few years ago, renewable energy prices, especially solar and wind, have gone down dramatically. Has the use of renewables increased in equal measures [1] Now we are seeing a new trend. With the cost decline that we've seen, there are big emerging countries like China and India, coming to the table with massive new targets. India has just declared that they will install 100 Gigawatts of solar and 40 Gigawatts of onshore wind by 2022.

\footnotetext{
* Corresponding author.
} 
This is a huge number [8] The needs in India are immense and their signal is a very powerful one for renewables. China has pledged 200 Gigawatts of solar and 100 Gigawatts of onshore wind by 2020. Now, these are remarkable numbers, and they will trigger very dramatic increases in investment in the power generation coming from renewables in the future [12]. The UAE is the first Gulf country to start on the new energy strategy, which involves the nuclear power and solar energy in addition to natural gas, which covers the majority of the UAE's needs. The country is looking to increase its target for power generation from clean energy to 30 per cent by 2030; it aims to achieve 25 to 30 per cent of its electricity to be generated from both nuclear and solar [2].

\subsection{Strategic objectives for $U A E$ regulations}

\subsubsection{Reduce UAE Ecological Footprint}

The UAE ecological footprint dropped to 7.75 hectares per person last year, down from 11.68 hectares in 2006, the decrease was because of improved environmental sustainability, through the country's adoption of the Ecological Footprint initiative. The UAE is the third country in the world to do so after Switzerland and Japan. According to the 2014 Living Planet Report, five countries - China, the United States, India, Brazil and Russia - account for 47.2 per cent of the world's ecological footprint. Despite UAE urban growth, which brings more carbon emissions and a greater ecological footprint, efforts to promote a greener economy and environmental policies have improved the situation. UAE has set standards to ensure lighting product imports are energyefficient, especially for the housing sector, which represents 57 per cent of the country's ecological footprint [7]. The Government also aims to develop standards for fuel and cars, to reduce carbon emissions Fig. (1)

\section{Ecological Footprint}

UAE enjoys a high level of human development, but at the cost of a large ecological footprint An Average person in the UAE consumes 10 times more energy than world average, emits 5 times more $\mathrm{CO} 2$ emission and consumes 6 times more electricity than world average
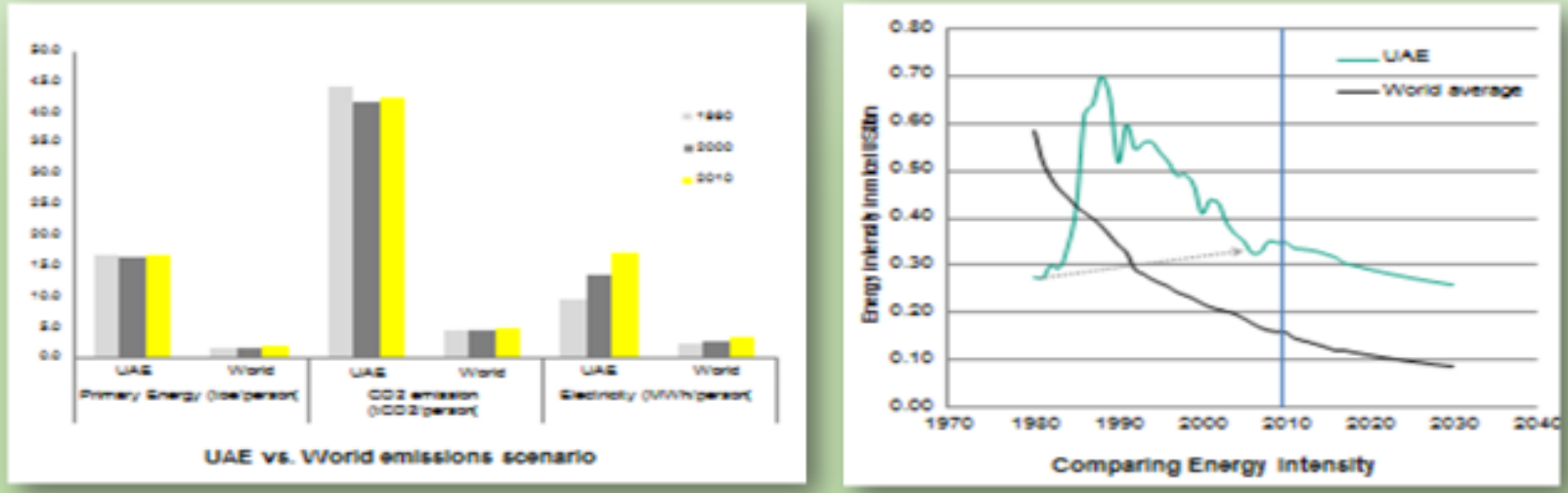

Figure 1: UAE Ecological footprint 


\subsubsection{Reduce Electrical Consumption by $20 \%$}

UAE aims to cut energy consumption by 20 per cent by 2020, Fig.(2). as it enforces an energy-efficient building project, "Buildings use 70 per cent of the energy that the country produce, "To get the country green, that needs to target the biggest consumer - the buildings, whether residential or commercial." The efficiency of the program, called the green building project, was started as an initiative in 2008 by the Supreme Council of Energy [11], Electricity and Water Authority. In 2011, it became mandatory for all government buildings to adhere to the program. [2]However, this year it was extended, requiring all new buildings to be energy-efficient Fig. (2)

\section{Energy Efficiency in buildings}

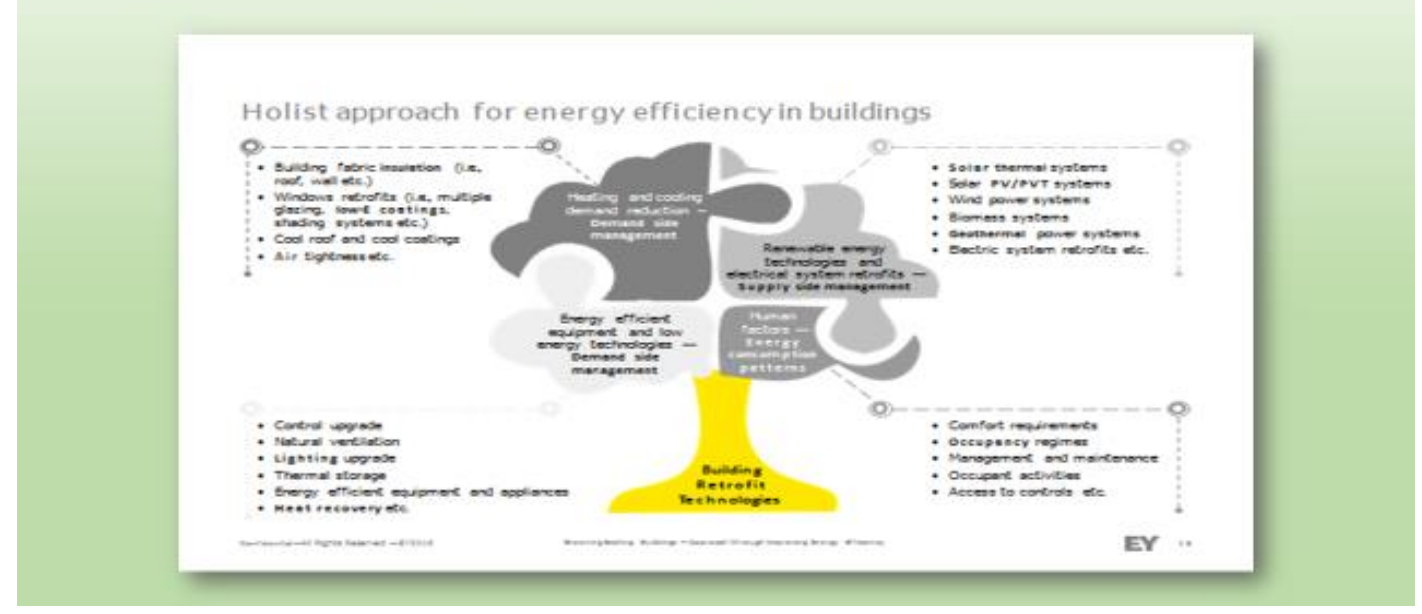

Figure 2: Holist approach for energy efficiency in buildings

\subsubsection{Reduce Water Consumption by $18 \%$}

The Federal Electricity and Water Authority (FEWA) has managed to save 53.44 million gallons of water last year. The 18 per cent reduction in consumption, as compared to that of 2014 , followed a nationwide conservation award that saw a stiff competition from housewives, schools and mosques. Schools set a big example by saving up to 35.34million gallons of water that represented 25 per cent cut as compared to 2014's consumption [3] , Those were followed by the mosques category, which saved 10.04 million gallons of water or 18 per cent drop in comparison compared to 2014's water consumption."Housewives came third after saving 8.1million gallons of water that represented nine per cent reduction in consumption compared to 2014's water consumption, The Eastern region (B) led the country in rationing with 13.42 million gallons of water saved or 30 per cent drop as compared to 2014's consumption,. However, the Western region (A) managed to save 16.71 million gallons of water, but that represented 22 per cent drop in comparison to 2014's water consumption, The Ministry of Justice, represented by the courts in the emirates of Fujairah, Umm Al Quwain, and Diba Al Hisn in Sharjah saved 584,186 gallons of water whereas the Ministry of Interior in Fujairah saved 188,380 gallons of water Fig.(4) . The Emirates Conservation Award is meant to promote conservative consumption of 
water and electricity, and instill the values of rationing in young generations [4], Participation is open to all nationalities. The list of winners included Emiratis, Arabs and Asians. The targeted conservation was 12 per cent, however, some families managed to reduce consumption by up to 60 and even 80 per cent [5] . FEWA in collaboration with strategic partners, has earlier installed 25,000 water-saving gadgets at 64 mosques and 60 schools . The award ,The first edition of the Emirates Conservation Award saw 2,810 residential participants, including 506 Emiratis and 2,304 expatriates, but only 1,124 were qualified. The list of top winners included 18 homemakers - three in each of the six regions involved in the competition.

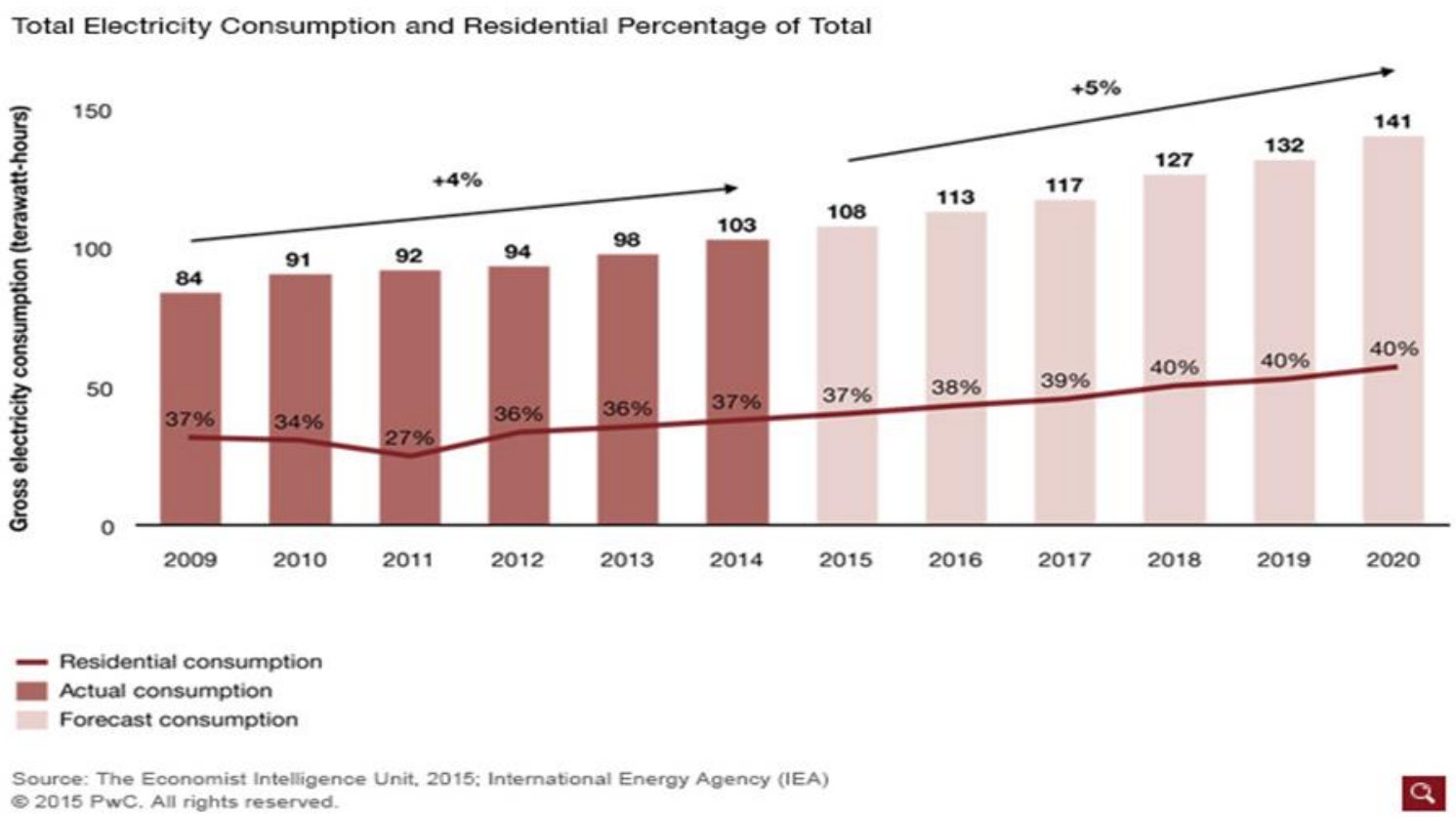

Figure 3: Total electricity consumption, with residential percentage of total

\section{UAE Enabling Strategies, Policies, Activities}

- UAE energy demand is expected to double by 2020 , water demand is expected to grow by $44 \%$ by 2025 (UNEP, 2013)

- The desalination fuel requirements alone will take up $20 \%$ of the total fuel production by 2030 (MoFA, 2012b)
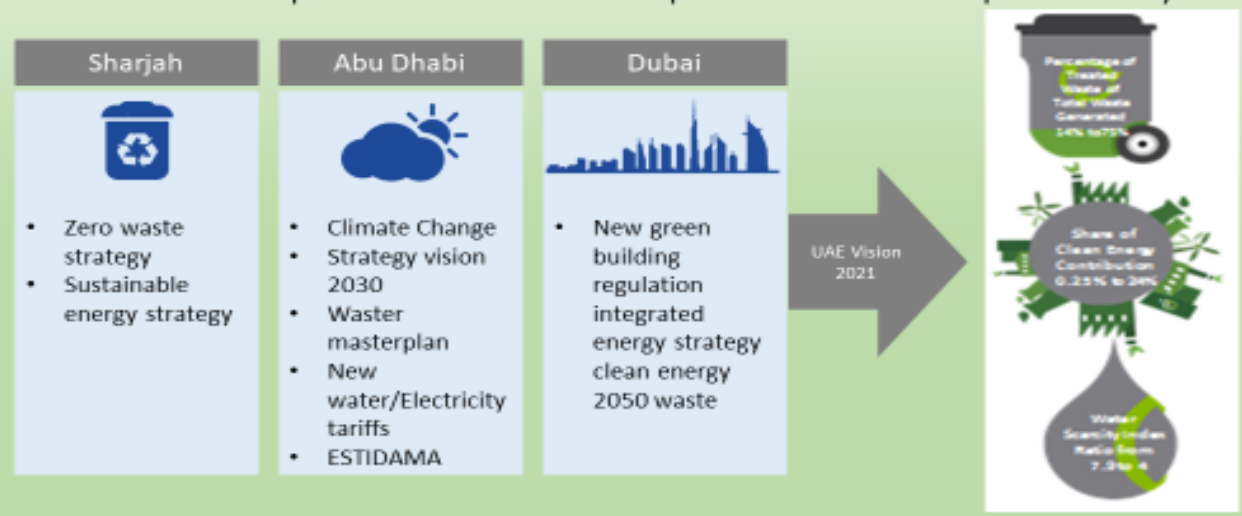

Figure 4: The growth of Water demand. 


\subsection{The difficulties faced UAE in changing to green}

It's not easy being green, at least in the UAE, where scorching summers make air conditioning as essential as the millions of gallons of desalinated seawater which keep most of the country's plant life from turning brown and crispy. But while the region has a well-founded reputation for having one of the largest carbon footprints, a number of projects demonstrate how environmental principles are at the foundation of many of the country's most exciting new developments. The prevalence of green buildings is growing all around the world, encouraged and frequently even required by both client demand and government policies. The net-zero energy goal being widely adopted requires a significant reduction of building energy consumption as well as the integration of clean, renewable local generation. Although reducing energy use is important, the truly exciting prospects for managing building energy needs lie with incorporating renewable energy resources into the built environment. Several renewable technologies that are commercially available today can completely cover the consumption needs of buildings. Consisting primarily of photovoltaic (PV) and wind turbine systems, these renewable technologies are, however, variable, intermittent energy producers [10]. To achieve the overall objective of mastering and optimizing energy use while also becoming more independent of the electrical grid, these energy resources can be coupled with storage or other more stable electricity generation technologies, such as combined heat and power generation (CHP). This post examines the various ways to achieve net-zero energy in buildings.

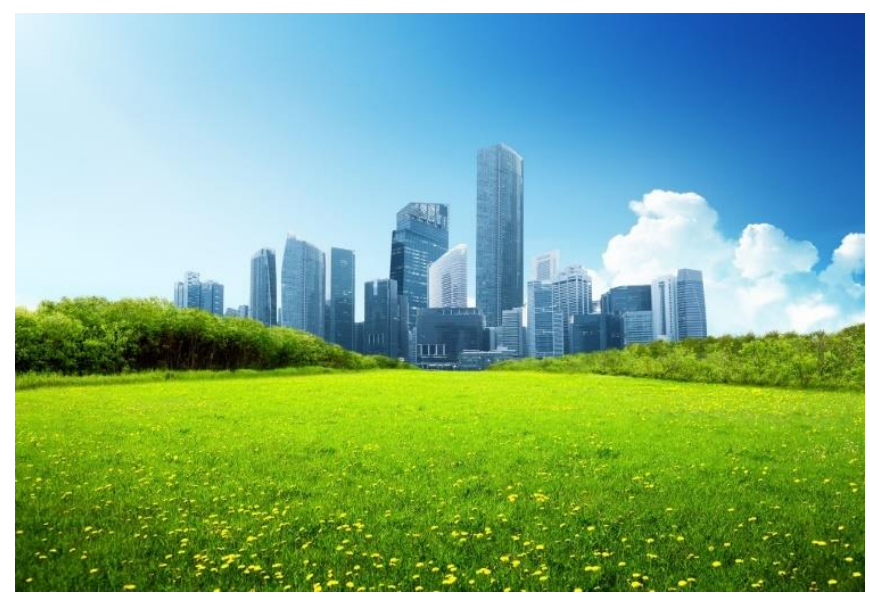

Figure 5: Active Houses Building Projects

Buildings project focuses on low energy buildings also called active houses, which are not only buildings, but active components in the overall integrated energy systems. The target is to demonstrate affordable solutions for social housing and revitalization of town areas. The solutions will reduce $\mathrm{CO} 2$ at no or negative cost seen in a total perspective [13]. Targeted CO2 reduction cost can be minus $€ 80$ /tonne taking the benefits of lower energy bills into account, to even better figures when national grants are included. It is possible to simultaneously save $\mathrm{CO} 2$ and money! Key barrier is the initial investment. See Figs. (6), (7) and (8). 


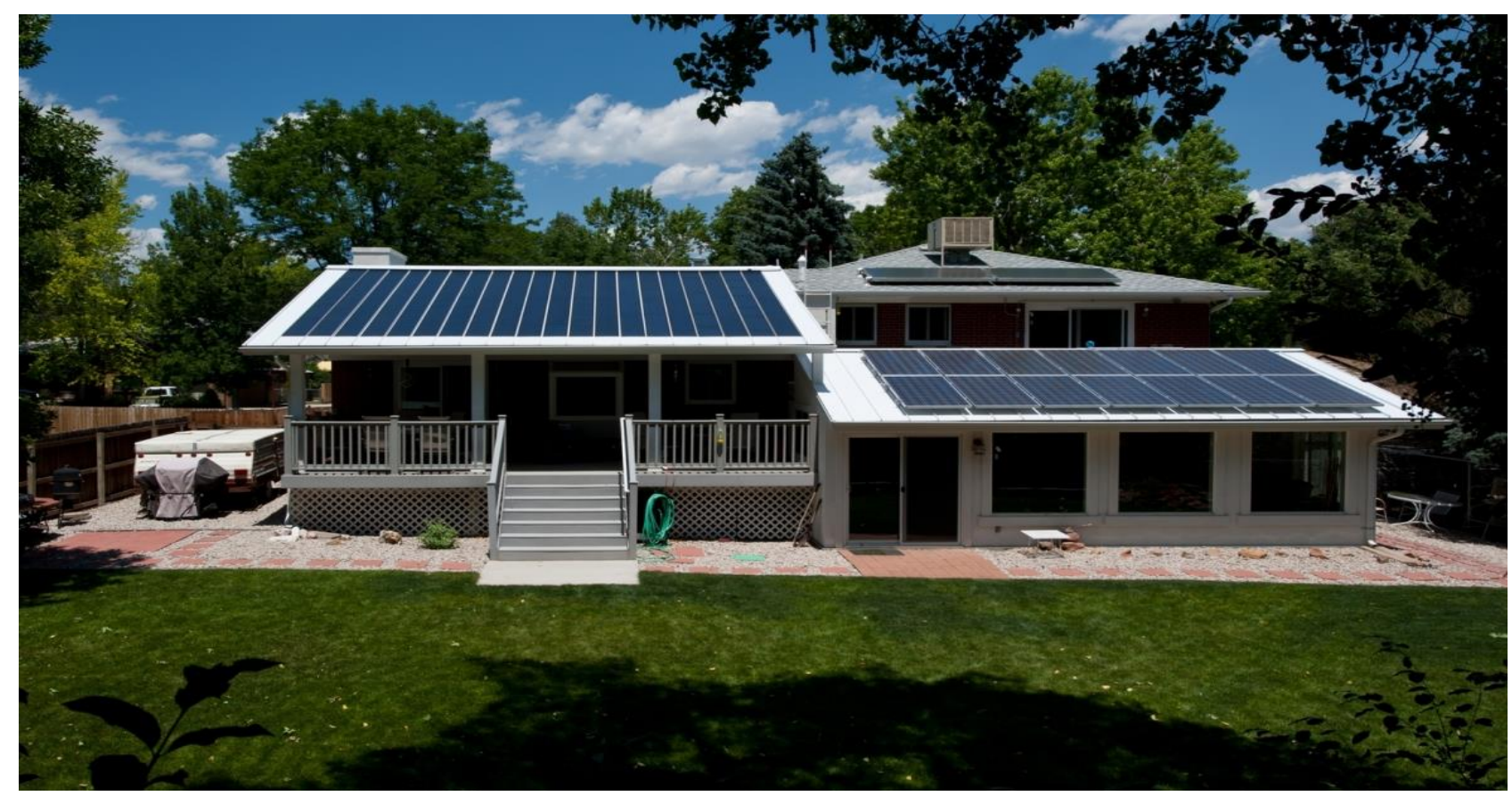

Figure 6: Active house depending on solar energy.

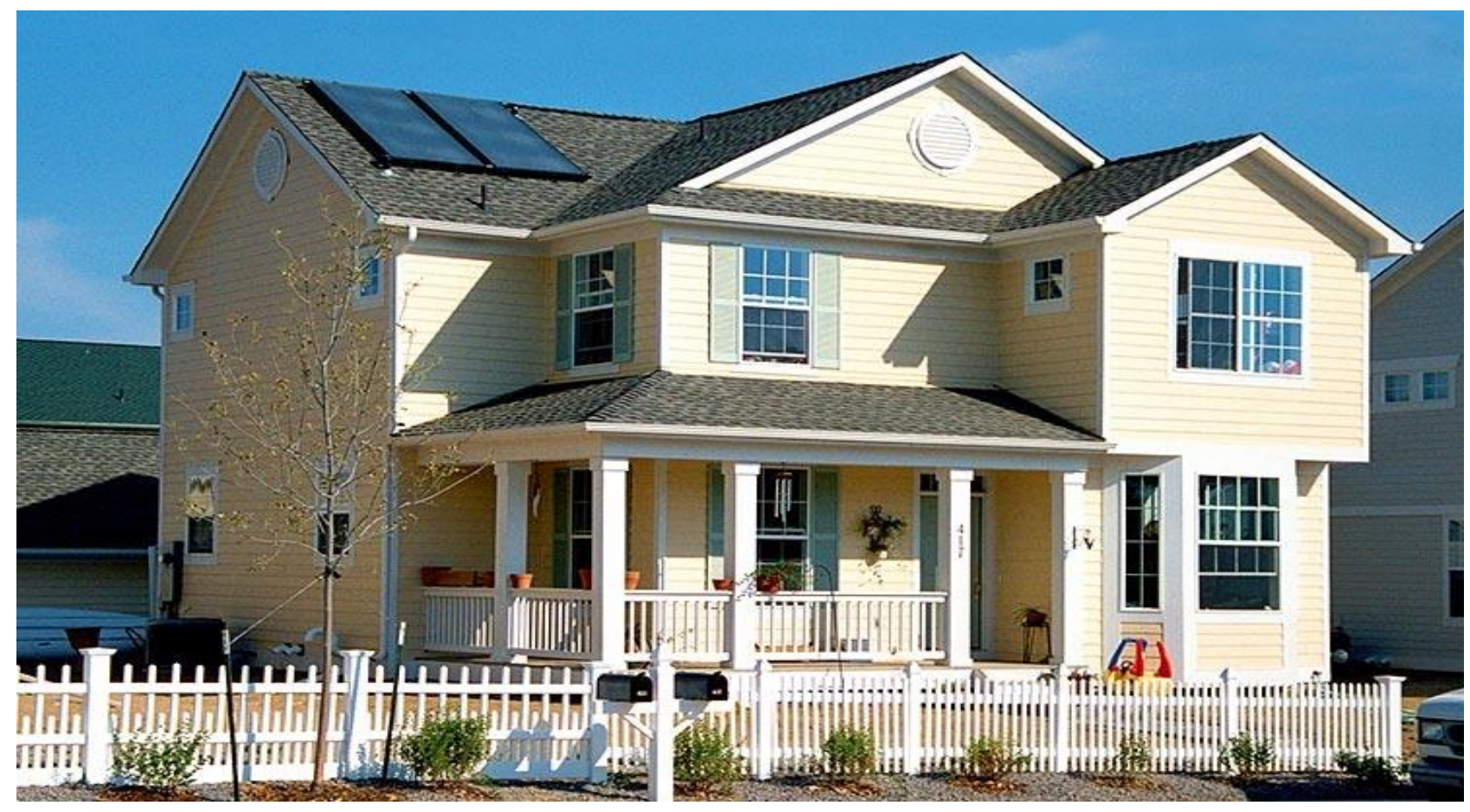

Figure 7: Another example of active house depending on solar energy. 


\section{Zonal Pressure Diagnostics}

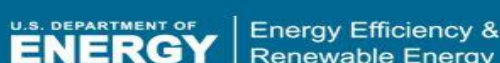

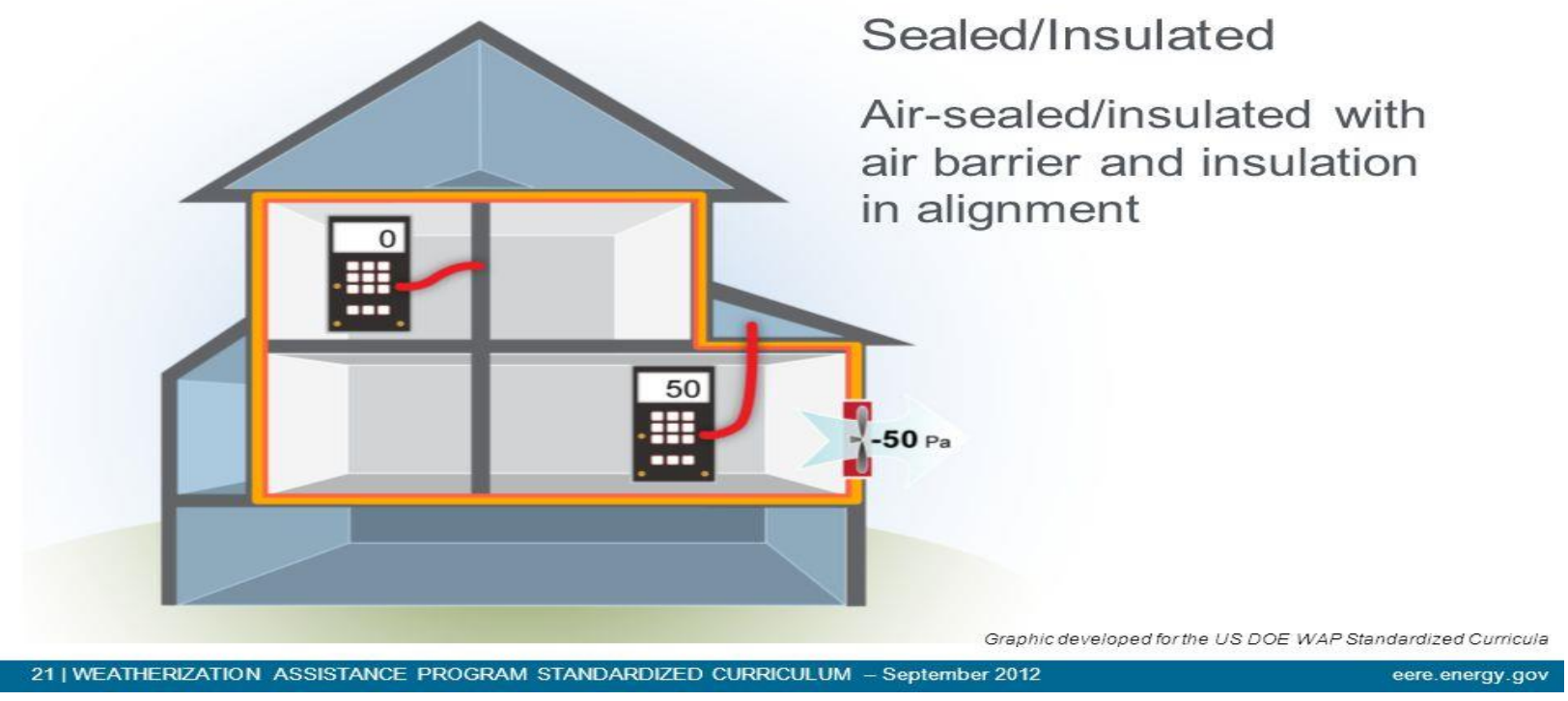

Sealed/Insulated

Figure 8: Active house depending on Air insulation[20].

\subsection{Examples of Renewable energy buildings in $U A E$}

\subsubsection{The Irena building}

Determined efforts are being made to introduce the first principles of sustainability in many aspects of life. Some of the most significant improvements have been made in construction, best illustrated by the official opening of the Abu Dhabi-based headquarters of Irena, the UN agency for renewable energy. Located in Masdar, the community which has come to represent the country's community to a cleaner environmental, the Irena building use 1,000 square meters of solar panels on its roof to cut its energy needs by 40 per cent and also using half as much water as other typical buildings in the city[16]. As a result, the building has become the first to receive a four pearl rating from Estidama, the certification system which measure the sustainability of new buildings in the emirate from the architects' drawing boards onwards, for everything from villas to schools and offices. 


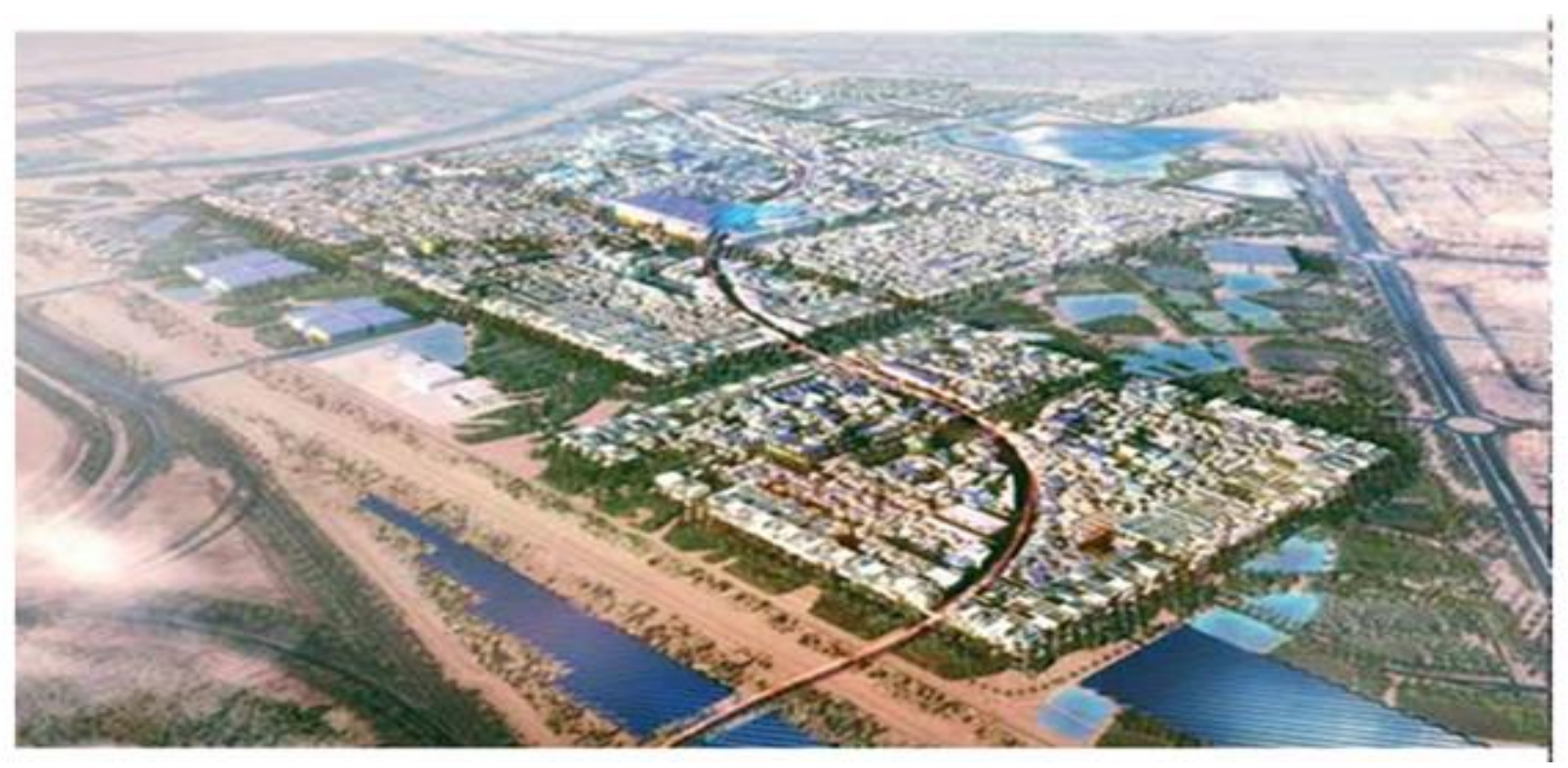

Figure 9: Masdar city in Abu Dhabi.

\subsubsection{Green airport}

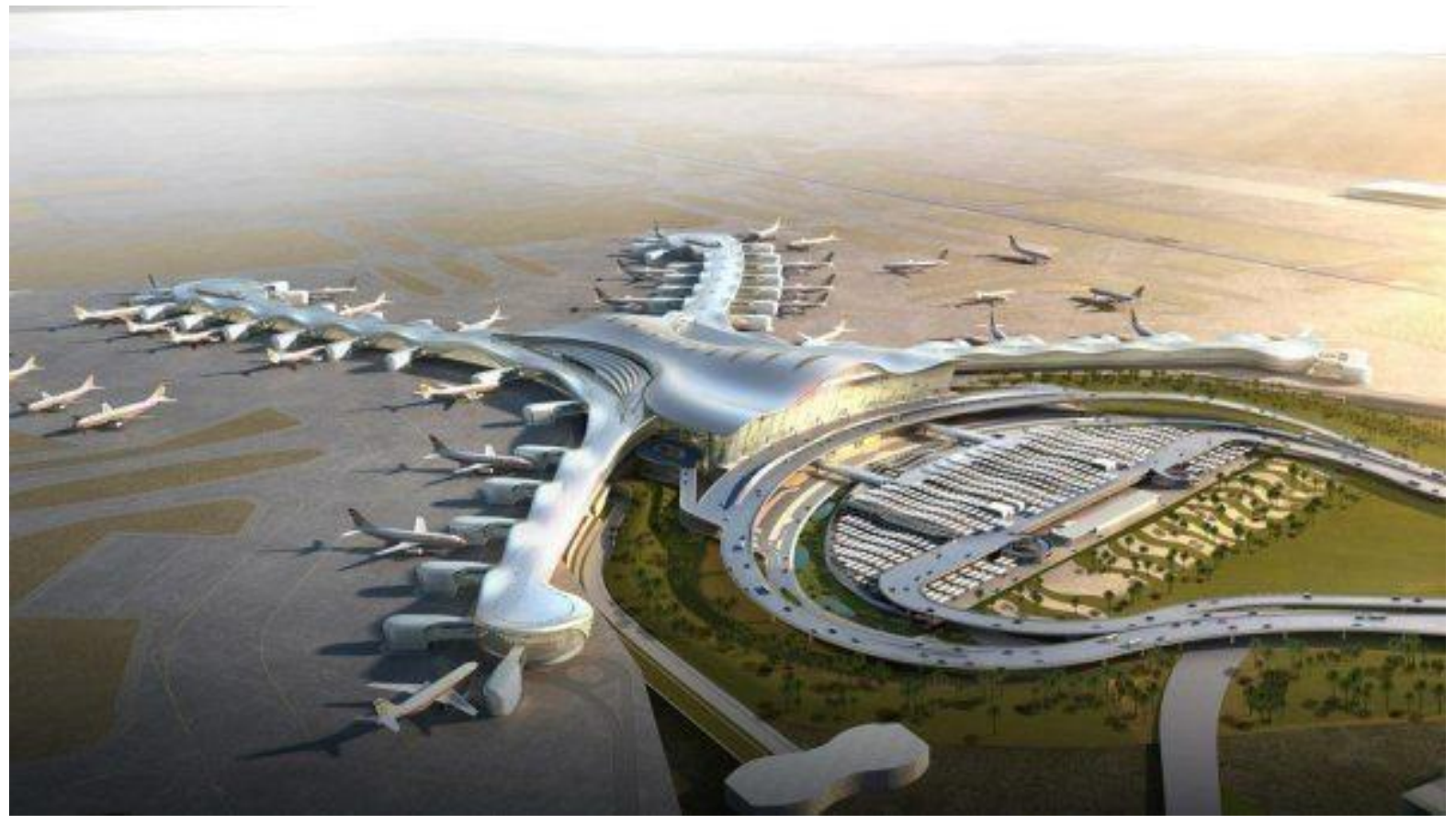

Figure 10: Green Airport, Abu Dhabi International Airport.

The Midfield Terminal will be the largest expansion in the history of Abu Dhabi International Airport, allowing over 20 million people to pass through each year by the end of the decade. While the airline industry is often criticized for its carbon footprint, on the ground the Midfield Terminal will be the largest building in the world to win environmental certification. It has already been awards a three pearl design rating from Estidama. What that means in practice, is that the terminal's design and construction materials will consume as little energy as 
possible, including a high-performance double glazing to keep out the heat of the Sun and "smart" air conditioning, lighting and ventilation on the inside[15]. An indoor park, with Mediterranean and desert themes will use recycled water, with water consumption reduced by 45 per cent and electricity use also significantly lowered. Even the terminal's construction is better for the environment, using recycled materials whenever possible and keeping up to three-quarters of building waste out of landfill dumps, see fig. (10),(11), and (12).

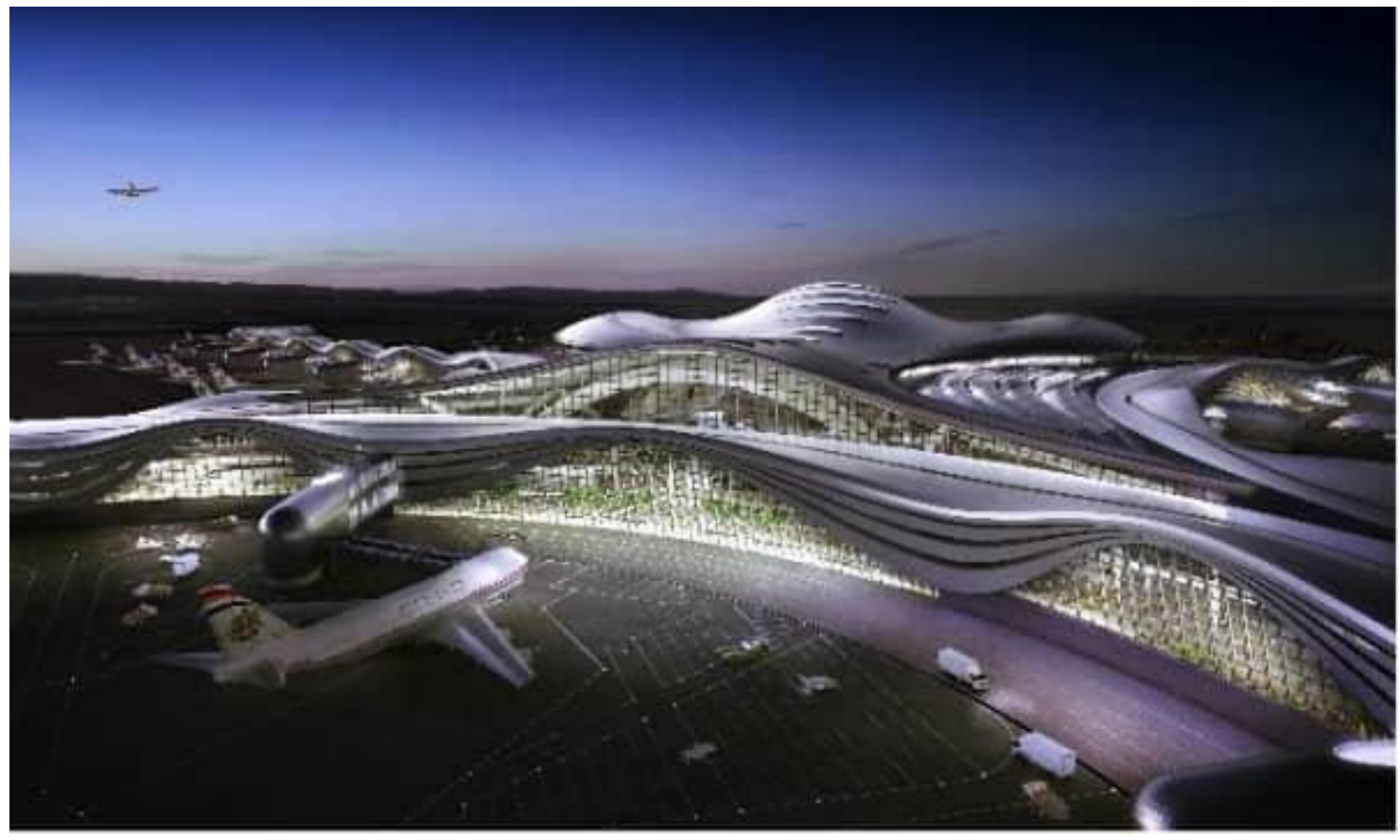

Figure 11: Green Airport Abu Dhabi International Airport,.

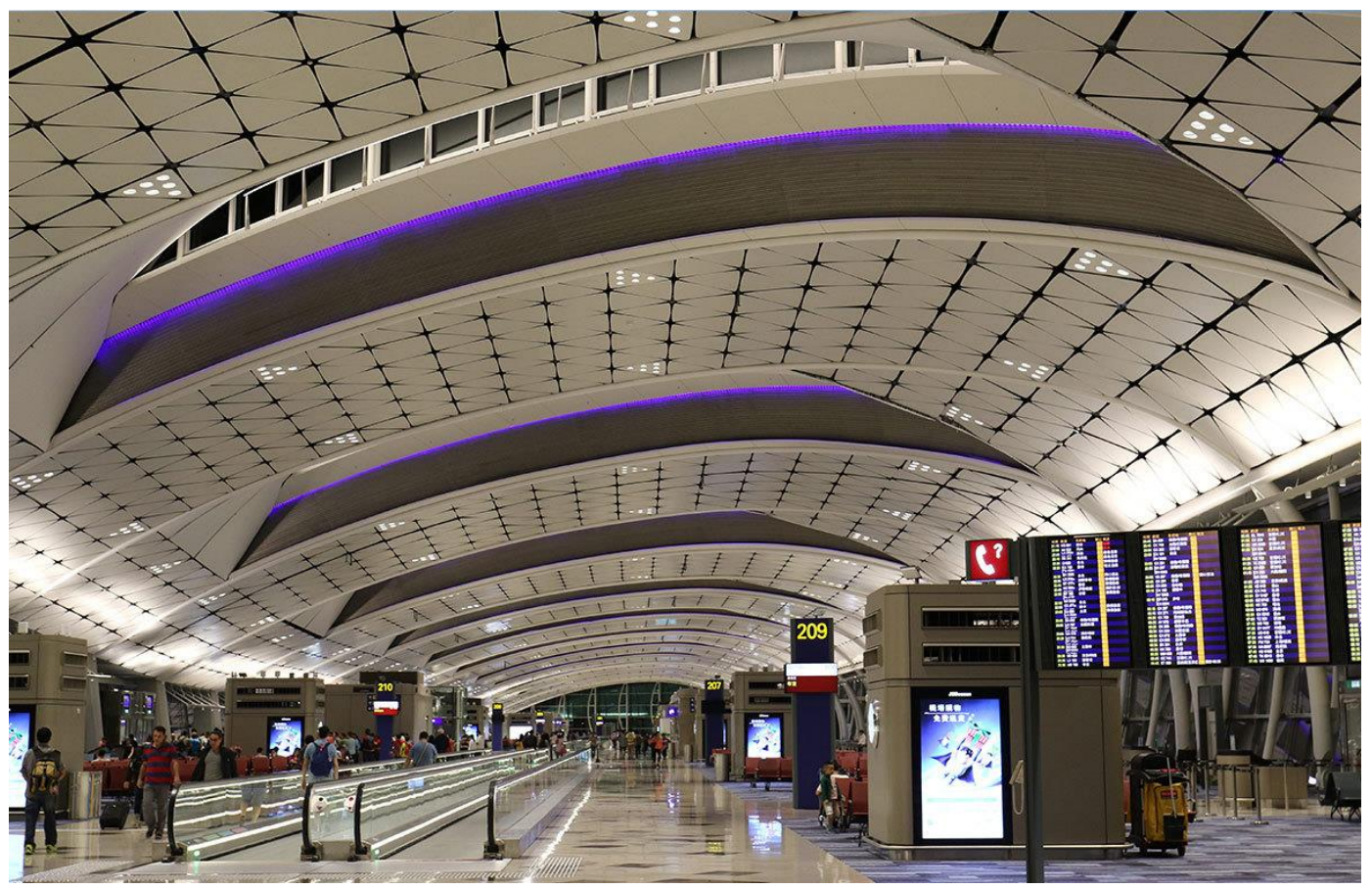

Figure 12: Green Airport Abu Dhabi International Airport. 


\subsubsection{Green museum}

Now approaching the final phase of construction, the Louvre Abu Dhabi has also been given a three pearl rating for its design. The museum's architecture, as well as being spectacular, is also highly energy efficient. Much of the structure, on Saadiyat Island, will be covered by a 180 metre diameter dome, which can be pierced by the Sun's rays which reducing its heat. Known as the "rain of light", this feature will shade visitors while reducing energy consumption by a third, fig. (13). It will also cut heat gain — the heat absorbed by buildings as they bake in the sun, by at least 70 per cent. It is not just the visitors to the Louvre Abu Dhabi who need protecting. The museum will be home to hundreds of precious antiques and artworks, including the only Leonardo da Vinci painting in the Middle East[19]. To prevent damage, the use of windows has been minimized, along with an energy efficient ventilation system and an irrigation network for the landscaping around the museum that is expected to reduce water consumption by over a quarter, fig.(14) and (15).

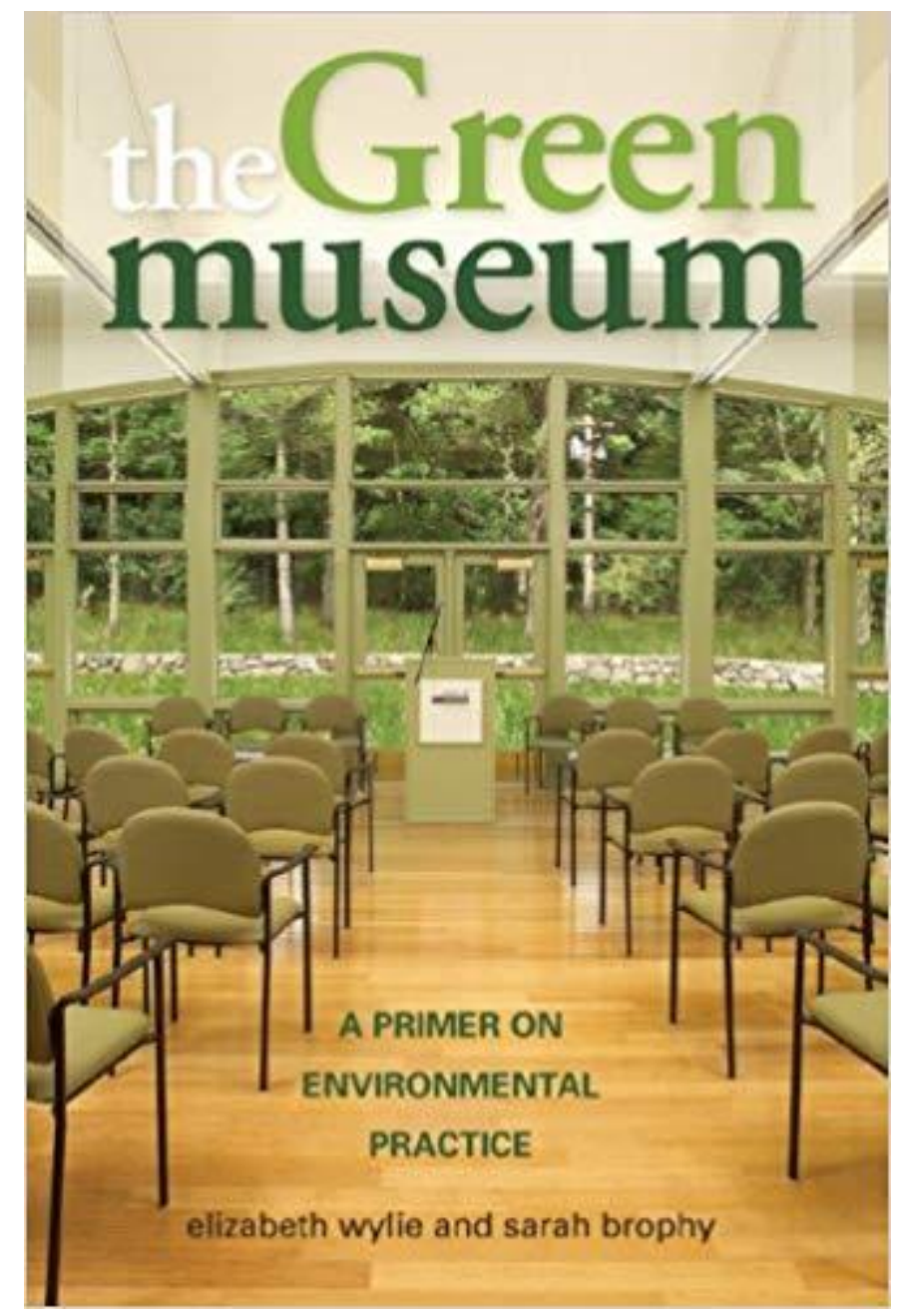

Figure 13: The Green Museum in Abu Dhabi 


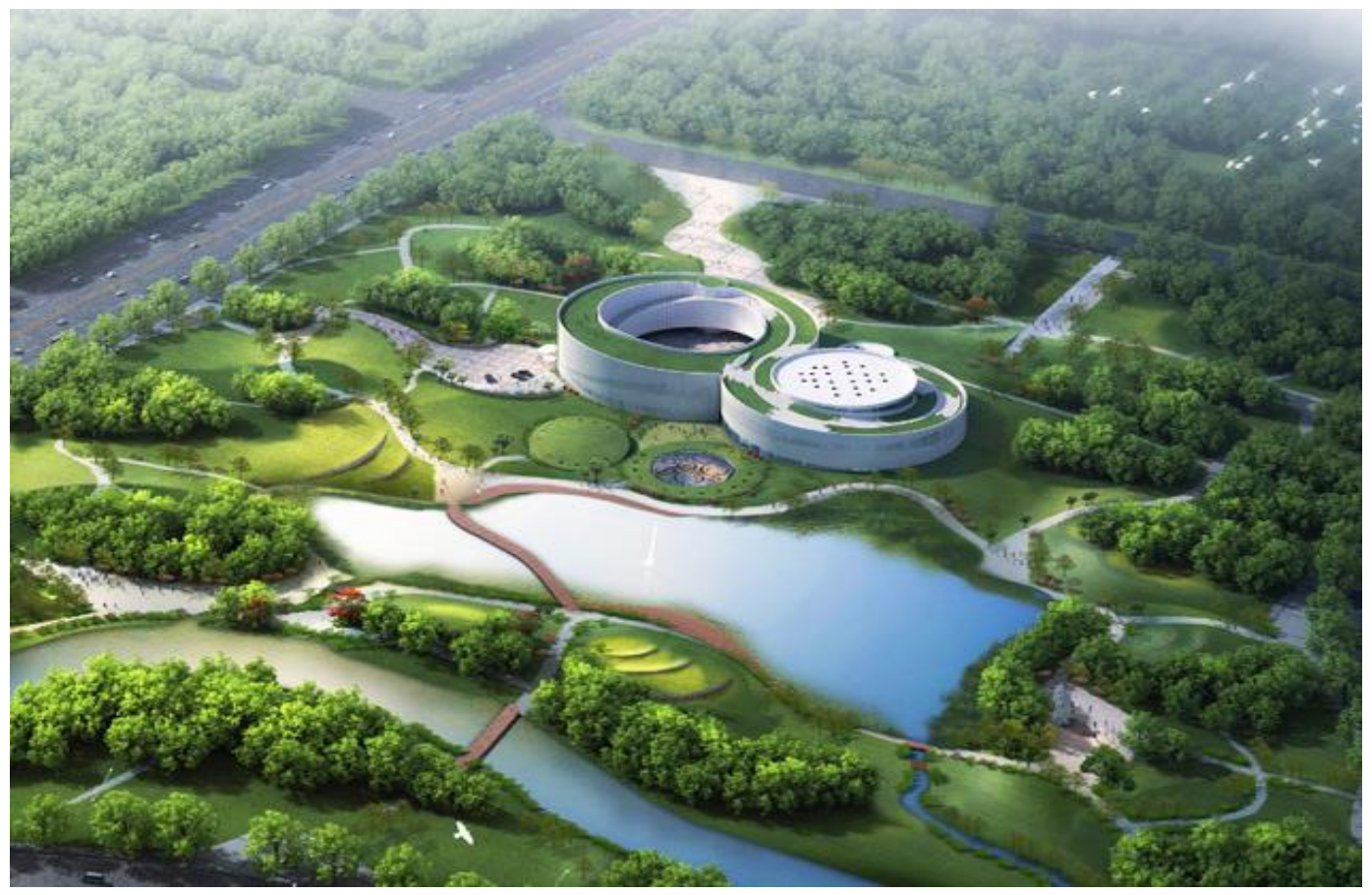

Figure 14: The Green Museum in Abu Dhabi

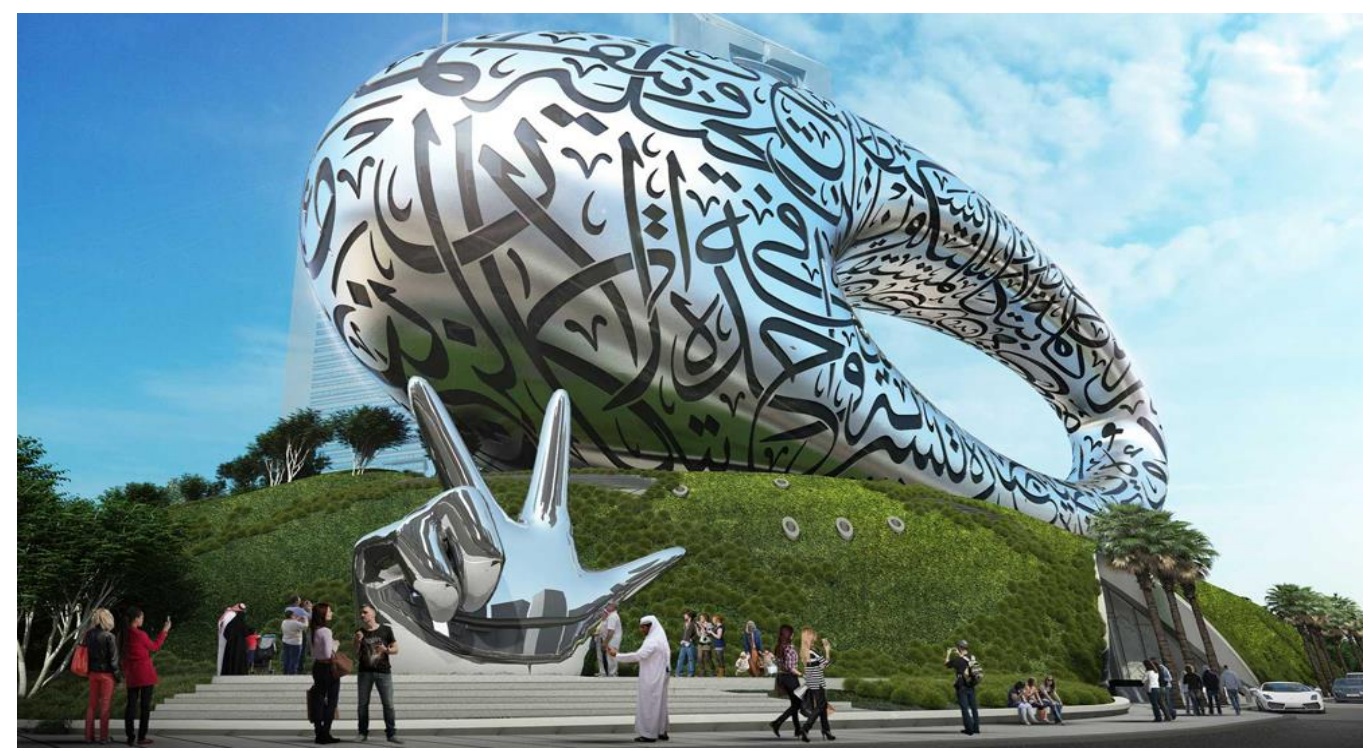

Figure 15: The Green Museum in Abu Dhabi

\subsubsection{Green mosque}

When it opened for worship last July, the Khalifa Al Tajer Mosque did not just welcome up to 3,500 people, but also opened its arms to environmental principles. Built in Dubai's Port Saeed district, to Leadership in Energy and Environmental Design (LEED) requirements, it has inevitably been dubbed the "green mosque" and hopes to win silver certification from the US Green Building Council[14]. Among the innovations in the building's design are controls on the water flow from the ablution taps and using waste water from washrooms to irrigate 
the plants around the mosque. Solar panels are used for water heating and the lights that illuminate the mosque, and its 25 metre high minarets Inside the building uses LED energy-saving lights, with a control system that automatically dims the interior outside prayer times[18]. Built by an anonymous sponsor, the mosque claims to be the first of its kind in the Islamic world, with the Awqaf and Minors Affairs Foundation (AMAF), the city's religious authority saying it is looking at a second green mosque in collaboration with the Dubai Multi Commodities Centre in the Jumeirah Lakes Towers area. Tayeb Al Rais, the secretary general of AMAF has said he hopes the mosque: "reminds worshippers of their duty to the environment."

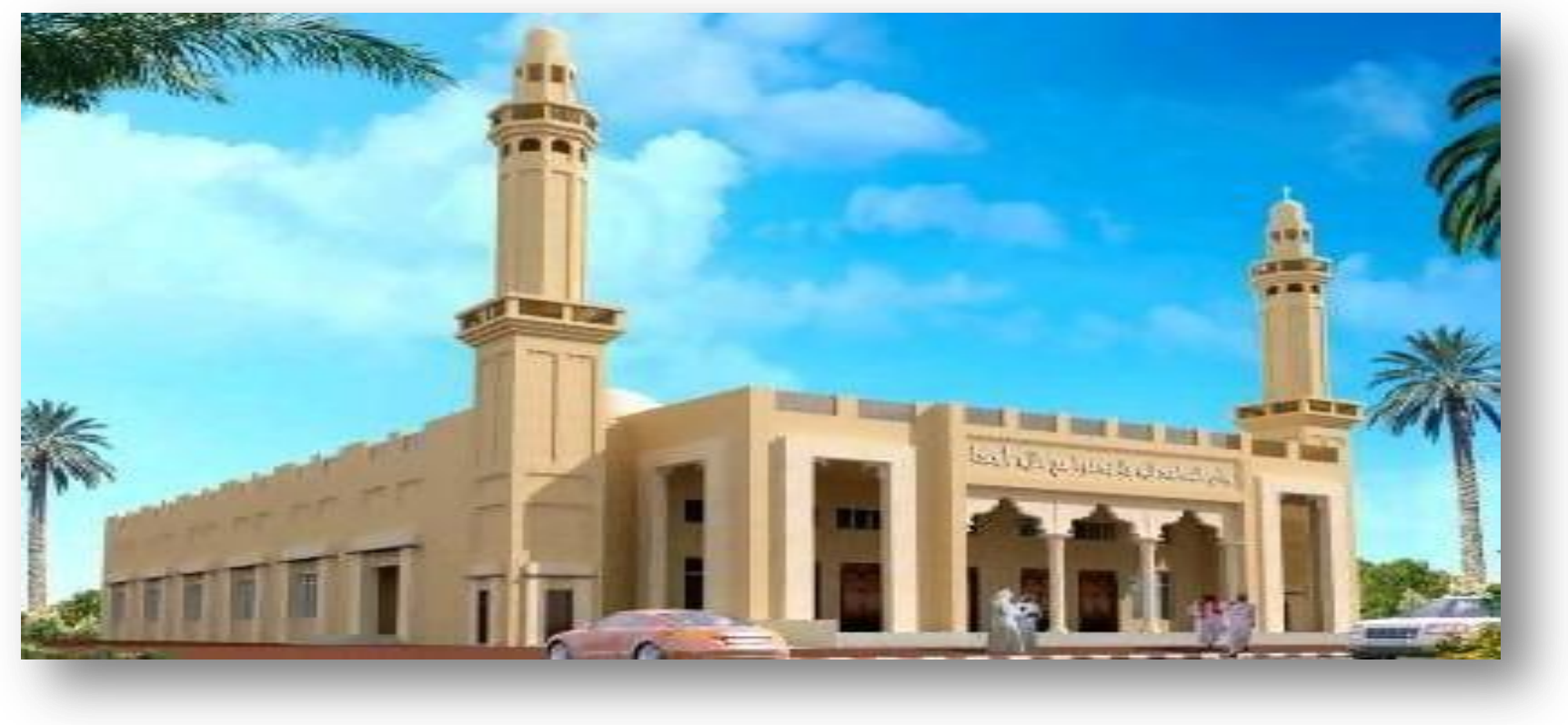

Figure 16: UAE's first eco-friendly mosque to be completed in 18 months

\subsubsection{Green skyscrapers}

Rising to 145 meters, the twin Al Bahr Towers have already made their mark on Abu Dhabi's skyline Fig.(17), as well as making the top 20 for innovative buildings in the 21 st Century by the Chicago-based Council on Tall Buildings. Built as the headquarters of the Abu Dhabi Investment Council, the structure's most intriguing and noticeable feature in an exterior covered in what looks like hundreds of parasols. The umbrella-shaped shades are inspired by something much older; the mashrabiya or lattice screens that were used the shade buildings in the Arab world for nearly 1,000 years and which is increasingly being adopted by modern architects[[17]. The "umbrellas" are automatically programmed to open and shut with the rising and setting of the Sun, keeping out the heat while allowing in light. The facade is said to reduce the heat transfer to the buildings' interior by half, reducing carbon dioxide emission caused by air conditioning by 1,750 tons a year. The towers have been given one of the first LEED silver ratings in the UAE. 

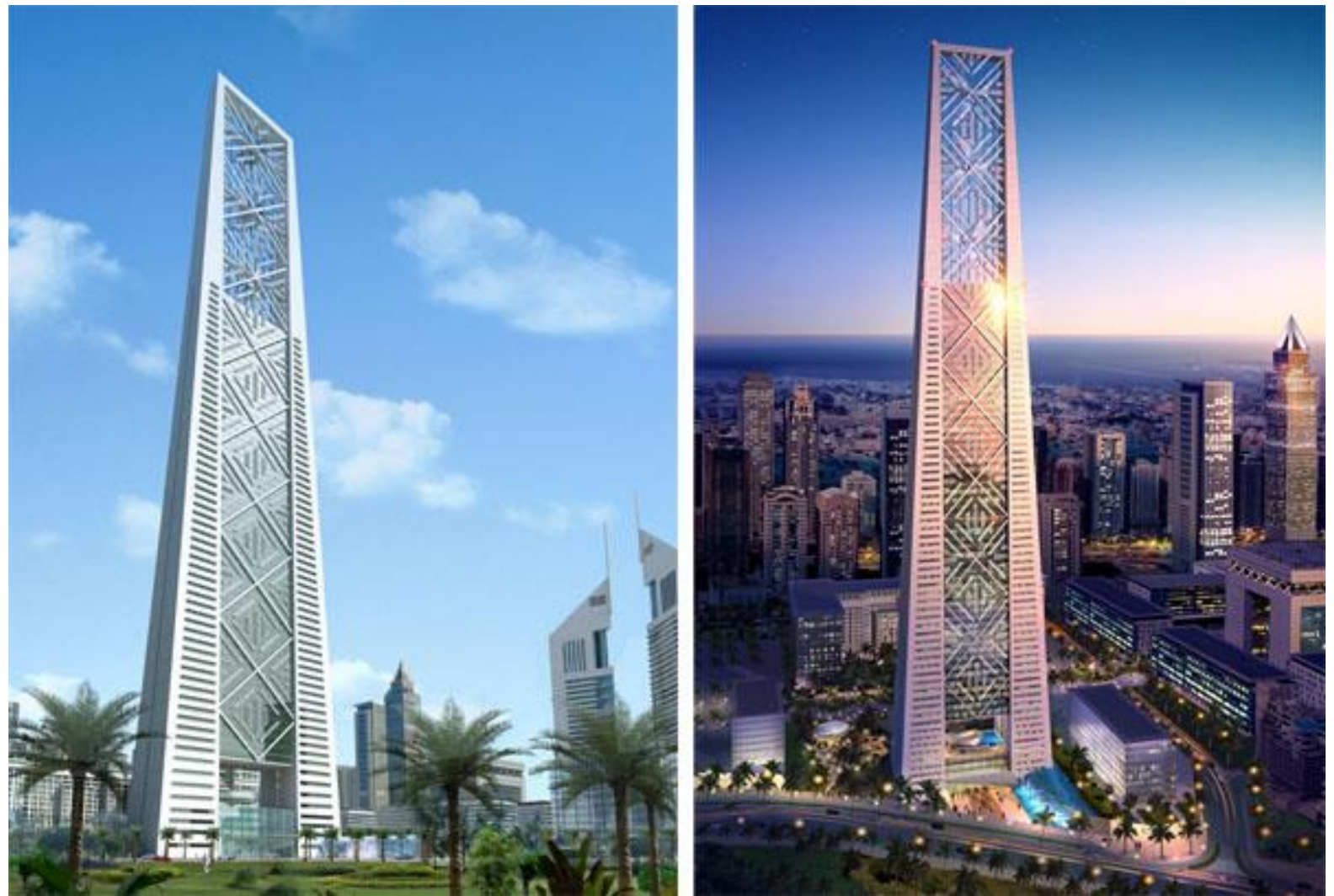

Figure 17: The Green skyscrapers twin Al Bahr Towers, Abu Dhabi.

\subsubsection{Green warehouse}

One of the most innovative and experimental projects also uses some of the oldest and most time-tested architectural principles. Based in Al Ain, the Sabla project aims to solve the problem of food storage in the developing world with the help of the date palm. The shelter being built is a series of domes and arches from woven palm fronds to create a strong but lightweight building [9]. It is inspired by the traditional arish homes, once found across the country until the advent of oil made concrete homes, with electricity and air conditioning, the norm. Using fronds and ribs from the palm, the arish is literally one of the greenest structures ever known. Walls, fences, roofs and floors can be built from mats of locally-harvested palm, along with the ropes that bind them. It can also be combined with the wind tower, a structure aligned to the prevailing breezes to cool interiors in a natural form of air conditioning. The team behind the Sabla Project includes craftsmen from Abu Dhabi Tourism and Culture Authority, specialists from BuroHappold Engineering and Sandra Piesek, a Polish architect who has spent six years experimenting with arishin Al Ain and Liwa. What the project shows, she says: "That the material, when combined with modern architectural and engineering thinking, can do other things that are new and innovative.

\subsection{How Renewable Energy is Creating Eco-Friendly Cities}

As the population of the world is growing, urbanization is developing rapidly in many cities around the world. People living compact in the same area can have many benefits. However, at the same time, pollution continues 
to increase in these areas. For example, air pollution rises as the demand for energy, transportation and various industries grow. Energy generation is one of the biggest causes of air pollution which contributes to harmful greenhouse gasses. For instance, these toxic gases get released during the production of energy which involves the combustion of fossil fuels such as coal and oil. Luckily, there are ways humanity can reduces its carbon footprint, with one of them being renewable energy resources. The green movement is a diverse scientific, social and political movement that addresses issues like harmful greenhouse gasses. By adapting to the green movement and implementing green resources in our cities, we are one step closer to a greener environment [6].

\subsubsection{Clean Energy in Cities}

Innovative technology that helps to decrease energy usage on a daily basis is on the rise. Small gadgets and appliances have become more energy-efficient, and specific renewable energy sources are being installed on a large scale in urban areas. The goal is to make cities greener through the use of clean energy, smart homes, and green construction. Several types of renewable energy resources are being implemented in urban areas that are slowly transforming our cities.

\subsubsection{Solar Energy}

By using solar panels, we can harness the energy of the sun's rays that provides our homes with solar energy. This solar energy can be used immediately to power buildings, or it can be stored for later use. Many companies have solar_technology under development, which is making it more efficient and affordable for everyone. This renewable energy source has great potential and can turn cities into solar cities that will provide clean energy for everyone.

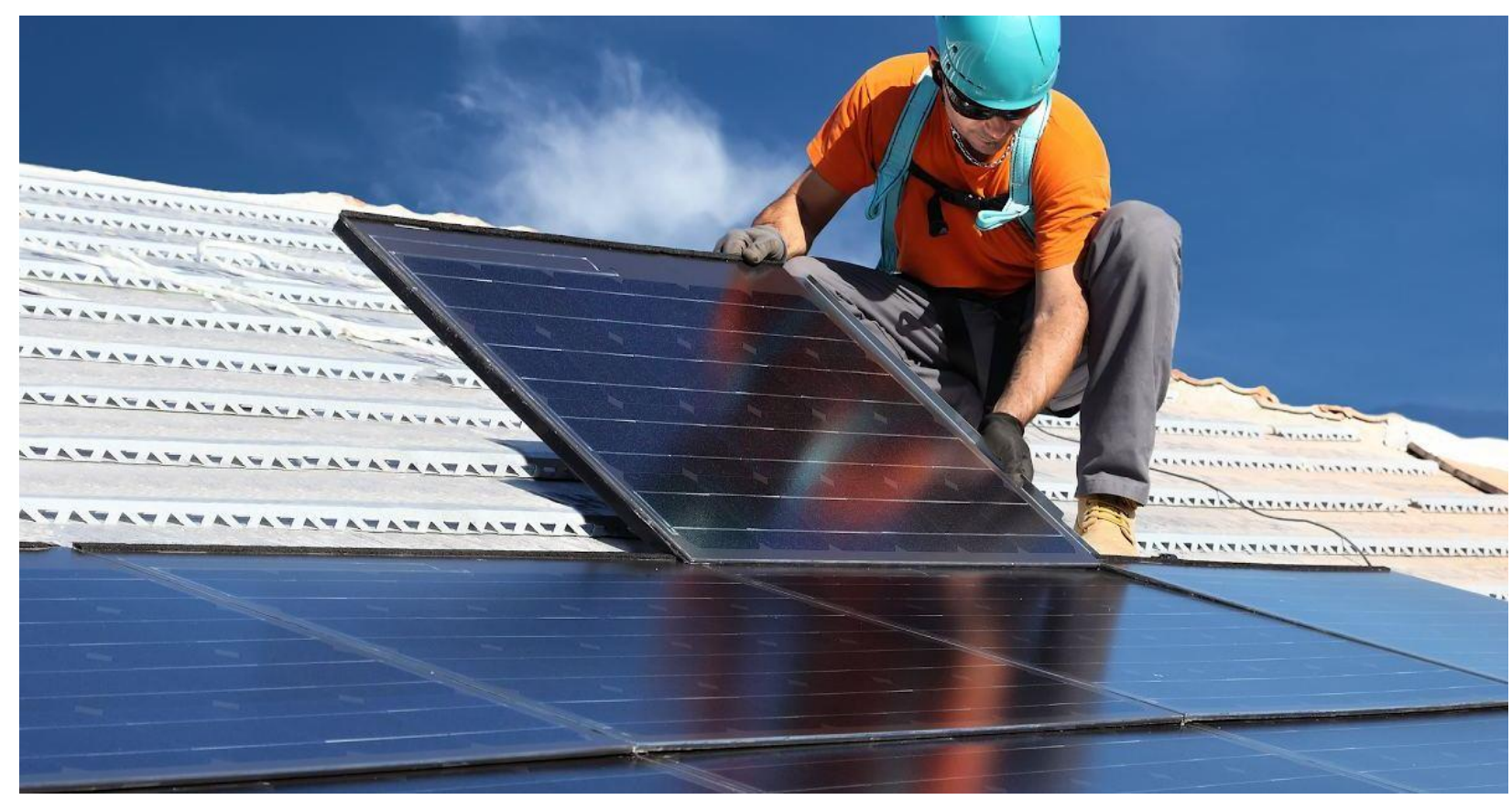

Figure 18: Fixing solar panels on the roof of the houses 


\subsection{Why Solar Is Still a Top Choice in Alternative Energy}

From wind to battery to water, alternative energy technology continues to change how we power our homes, office buildings, and even our cars. But solar power remains a front runner in the alternate energy industry. Solar energy, which is derived from the sun, is harnessed through photovoltaic (PV) cells. These cells directly turn sunlight into electricity, allowing solar energy to be used to power homes and other buildings. And this technology is nothing new. Scientists discovered that sunlight alone could be converted into electric power via solar cells in 1876. The first commercial solar cells became available in 1956, an U.S. and Russia's space programs used solar to power satellites in the late '50s and early '60s. Solar cells became much more affordable starting in the 1970s, and the technology has continued to infuse itself into energy infrastructure around the world since then. Over the last 10 years, use of solar energy has grown by $68 \%$. Are you considering having solar panels installed? While change can be hard, switching to solar energy offers numerous benefits. Here are four compelling reasons to embrace the green technology.

\subsubsection{Solar Is Eco-Friendly}

Going green has been a trend for the last few years, and it doesn't seem to be going away any time soon. Unlike conventional power sources, solar power doesn't emit chemicals that harm the environment.Using fossil fuels to power our homes and other buildings causes all sorts of harmful emissions including:

- Carbon monoxide

- Carbon dioxide

- Nitrogen oxides

- Sulfur dioxide

- Heavy metals such as Mercury

Solar energy is renewable and, most importantly, clean. With this form of energy, there are no worries of greenhouse gases, increased risk of acid rain, or increases to ground-level ozone. In fact, scientists are working on new solar cells that "use a photosynthetic material in algae to capture solar energy, directly converting it into electricity," Earl Reser writes. "Once these 'living solar panels' are ready for use, they will emerge as an environmentally-friendly and low-cost approach to harness solar power and generate green energy."

\subsubsection{Durability}

While solar panels can cost thousands of dollars, the cost is well worth proven durability. Since solar panels aren't easily damaged and have no moving parts, the risk of something going wrong is very slim. In turn, you can have peace of mind that you'll rarely experience an interruption in service. Today's solar panels are extensively tested to ensure that they can withstand extreme weather conditions including high winds as well as heavy rain, snowfall, and even hail. In the event that your solar panels were to break, most are covered with a long-term warranty.

\subsubsection{Extremely Reliable}


Solar energy is also extremely reliable. One of the biggest myths about solar power is that energy is generated from the sun. The fact is that energy is derived from daylight. This means that even on rainy or cloudy days, the panels are still able to produce energy. Solar panels are meticulously placed to ensure that they can accumulate energy in the morning and afternoon hours, creating electricity that will last for days to come. Since your home will remain connected to the grid, excess energy that your home creates is pushed back onto the grid. This causes you to have electricity costs credited to your account. That's right, you can actually make money by having solar panels installed on your roof [17].

\subsubsection{High Return on Investment}

Many of the home improvements that you'll make to your home will rarely add what you've paid to the value of your home. With solar panels, you will save money on your monthly energy bill which helps to balance out the cost of the panels. As an added benefit, solar panels typically add value to your home, which means you can make money when selling your home. In fact, a study found that potential homeowners are willing to pay $\$ 15,000$ more for a home that has solar panels. In a competitive market, having solar panels could be the factor that sets your home apart from others in the area. This means less time on the market and a quicker sale!

\subsection{World's biggest Concentrated Solar Power project in Dubai}

The cost of producing solar power in Dubai is the lowest in the world today, the goal is for 75\% of Dubai's energy needs to be met by clean power by 2050, a goal we gladly embrace. Fig. (19) and (20). Sustainable development is essential for the prosperity of our and future generations[11].

\section{World's biggest Concentrated Solar Power project in Dubai}

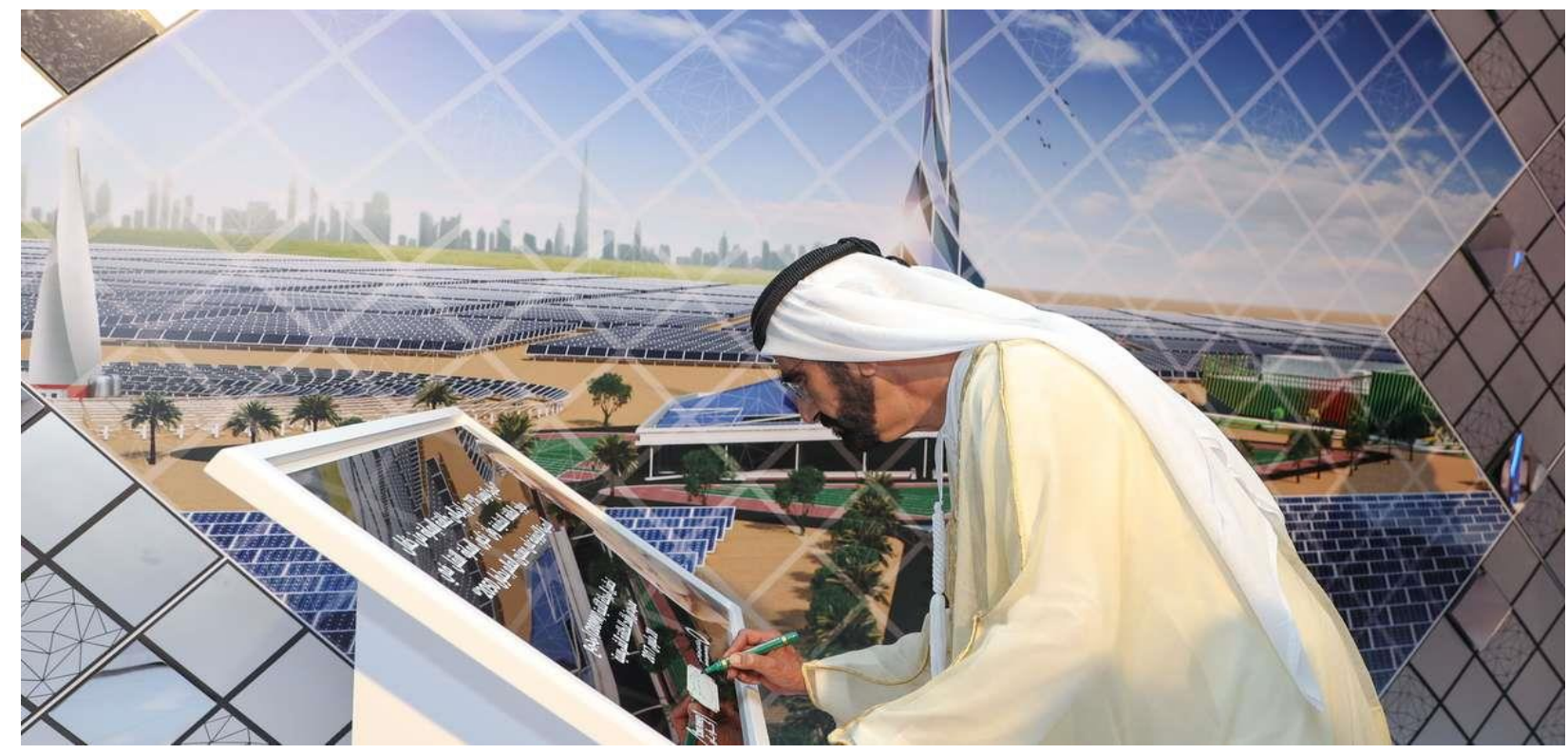

Figure 19: Shaikh Mohamed bin Rashid Prime Minister of UAE signing the biggest solar project 


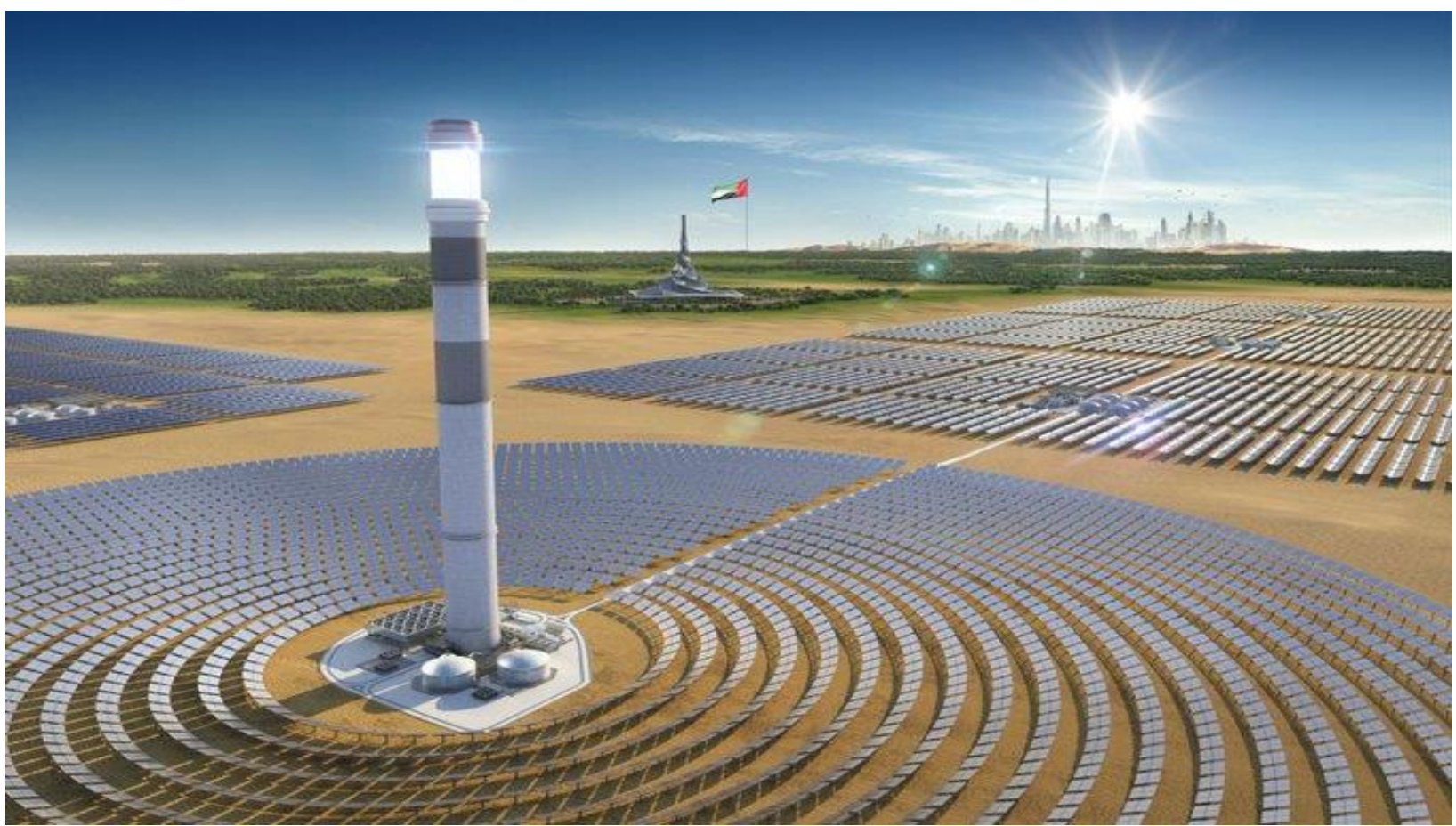

Figure 20: World's biggest Concentrated Solar Power project in Dubai

Once completed, the Emirati green energy landmark project will altogether generate 1,000 megawatts of clean energy by 2020 and 5,000MW by 2030, with total investments of Dh50 billion (about $\$ 13.5$ billion).

\subsection{UAE on list of Top 10 green building nations}

Emirates has "cool" buildings that are more livable and energy-efficient, says US-based council The UAE is ranked ninth among the Top 10 nations with the biggest energy-efficient buildings outside the US, the Green Building Council (GBC) has announced [13]. The US-based council, an industry body that promotes costefficient and energy-saving buildings, released its ranking for LEED (Leadership in Energy and Environmental Design) outside of the United States. GBC said the latest list, based on figures as of April 2014, demonstrates the global transformation of the built environment into healthy, high-performing structures that benefit its dwellers. The UAE ranked ahead of Finland. Canada topped the list, followed by China, India, South Korea, Taiwan, Germany, Brazil and Singapore. However, the UAE currently has nearly 10 times the number of LEED-registered projects than Singapore, based on the current projects. Among the notable projects in the UAE, the council cited, is the Dubai Electricity and Water Authority Headquarters, which has a LEED Platinum rating (highest possible under this system). The ranking of the top 10 countries for LEED outside of the US is based on cumulative gross square meters (GSM) of space certified to LEED in each nation as of April 2014. In South America, Brazil stood at No. 7 on the list, with 2.85 million GSM, while the United Arab Emirates represented green building success in the Middle East, at No. 9 with 1.82 million GSM of LEED-certified space[22].

\subsection{Dubai ranked third in the list of most green buildings in world}


Emirate's residential segment lags in LEED certification race, Core Savills, in a report titled "Sustainability and Wellness in Dubai", said the emirate has over 550 projects under LEED certification with London and New York leading the race with 2,600 and 900 buildings, respectively[21]. Dubai has the highest ratio of projects being certified with 81 percent of in-progress projects across global cities, which indicates a "burgeoning interest in sustainability". Fig.(21). Overall, the UAE is ranked amongst the top 10 countries to hold LEED certification outside the United States. China heads the pack followed Canada and India[23]. Despite buildings being built as per LEED guidelines, headline rents in Dubai remain at par with other non-certified Grade A stock due to developers launching initial project phases at "attractive entry price point" to achieve critical mass for their future phases, and green developments containing to compete with established, centrally located noncertified Grade A stock.

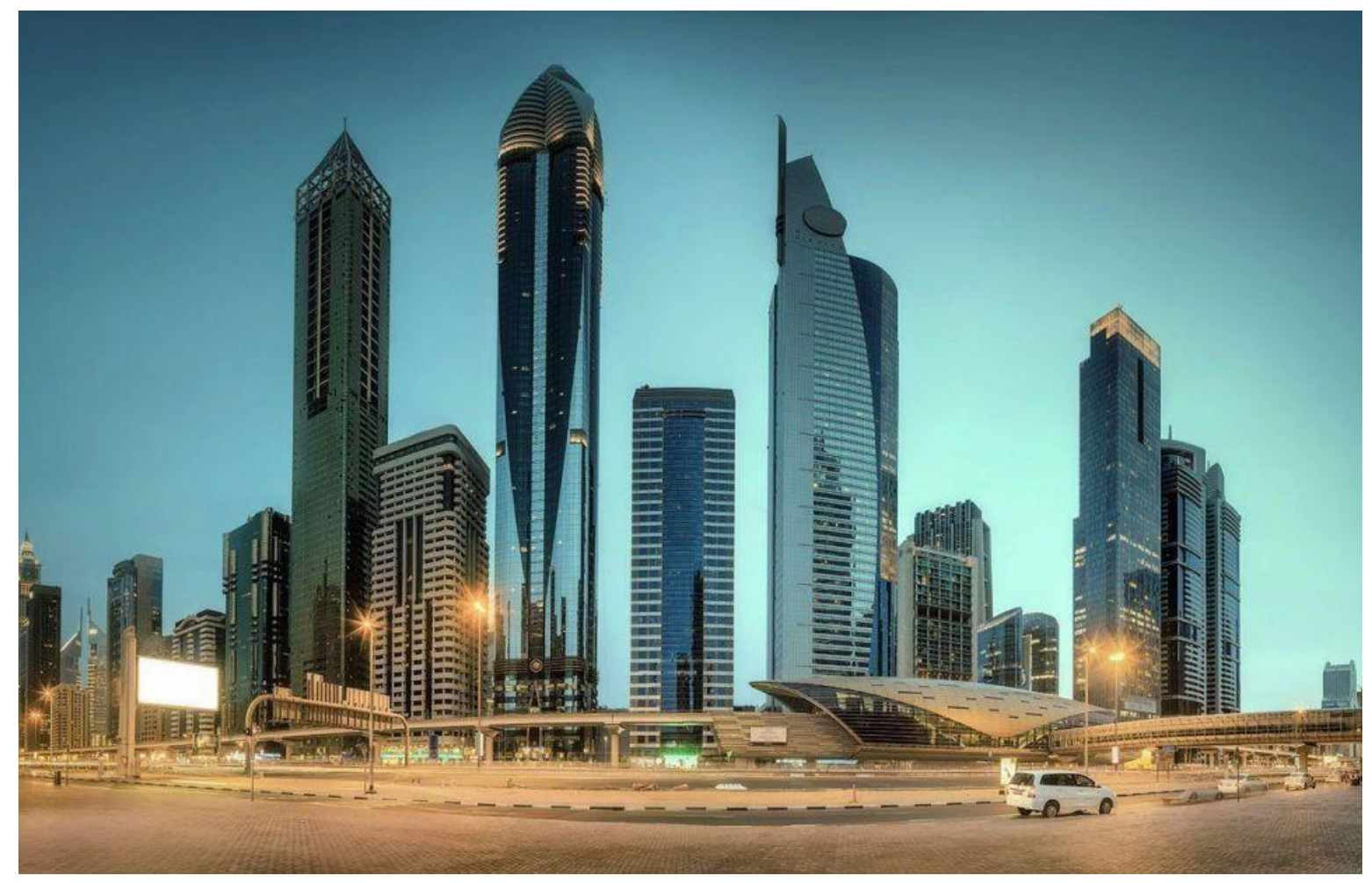

Figure 21: Dubai is ranked third in the list of global cities with the highest number of green buildings.

Last year, Dubai Municipality made in mandatory for all existing and new buildings to implement green building standards to achieve a smart, sustainable city status for Dubai by 2021.

\section{Conclusion}

The expected impact of using renewable energy in buildings in UAE is:

- $\quad 88 \%$ reduction in energy use and $0.003 \mathrm{Mt}$ of $\mathrm{CO} 2$ savings per year

- $50,000 \mathrm{~m} 2$ of new build efficient area

- 366 dwellings involved and an estimated 970 end users engaged

- $1,500-20,000$ people reached by dissemination activity 
- $4 \%$ return on investment

- $\quad$ EUR 50 million investment from project partners

- Key training actions: training of designers

- 5 technologies taken to market.

\section{References}

[1]. Building next-generation sustainable cities: A road map for economic, social, and environmental sustainability, Strategy\&, 2014.

[2]. DEWA saves Dh752m through energy efficiency measures," Emirates 24/7, April 8, 2015.

[3]. DEWA extends its $24^{\circ}$ Celsius campaign to the commercial sector," DEWA website, August 13, 2014.

[4]. Unlocking the potential of district cooling: The need for GCC governments to take action, Strategy, 2012.

[5]. Achieving a sustainable water sector in the GCC: Managing supply and demand, building institutions," Strategy\&, 2014.

[6]. Riadh Al-Dabbagh, 2012, Potential role of UAE in promoting environmental technology.

[7]. European affords of social sciences, vol.2, 2012.

[8]. Prof. Riadh Al-Dabbagh, 2017, Why do we need to reduce the carbon footprint in UAE, Chapter 12, SPRINGER, sustainable Building for a cleaner Environment, 2017.

[9]. United Nations Environmental Program: UNEP, 2013, annual report.

[10]. .Ministry of Foreign Affairs: MOFA, act amendment, 2012.

[11]. Intergovernmental panel on climate change: (IPCC ) 2007.

[12]. Super council of energy report, 2008.

[13]. .United Nations Environmental Program: Path towards sustainable development, UNEP 2011.

[14]. NAHB, Icc 2007, National green building standards.

[15]. LEED 1998, USA green building council leadership in Energy \& Environmental design.

[16]. Core Savills, (2017) a report titled "Sustainability and Wellness in Dubai".

\section{Internet Resources}

[17]. 16. www.Siemens.com/energy efficiency

[18]. www.diag.org.Uk / documents. jsp.

[19]. Www.carbontrust.co.Uk / publications.

[20]. www.greenbuilding.com

[21]. www.total.com/ energy/Efficiency.

[22]. Www.dubaicityguide.com/

Dubai

City

Guide.

22.https://www.google.ae/url?sa=i\&source=images\&cd=\&ved=2ahUKEwj3jPP4j6rfAhVBWxoKHann AsYQjhx6BAgBEAM\&url=http\%3A\%2F\%2Fwww.aromacontracting.com\%2F\&psig=AOvVaw26Tc C_T1U_D9-cwMSSek50\&ust=1545247566691598.

[23]. www.dmgevents-me.com/gaiaAwards.

[24]. www.thebig5.ae. 